Article

\title{
Effect of Biochar and Irrigation on the Interrelationships among Soybean Growth, Root Nodulation, Plant P Uptake, and Soil Nutrients in a Sandy Field
}

\author{
Hua Ma 1,2,*, Dilfuza Egamberdieva 1,3, Stephan Wirth ${ }^{1}$, Qirui Li 1,4,5 (D), \\ Richard Ansong Omari ${ }^{1,2}$, Mudan Hou ${ }^{6}$ and Sonoko D. Bellingrath-Kimura ${ }^{1,2}$ \\ 1 Leibniz Centre for Agricultural Landscape Research (ZALF), 15374 Müncheberg, Germany; \\ egamberdieva@yahoo.com (D.E.); swirth@zalf.de (S.W.); leolee8612@gmail.com (Q.L.); \\ talk2jafakingonline@gmail.com (R.A.O.); belks@zalf.de (S.D.B.-K.) \\ 2 Faculty of Life Sciences, Humboldt-University of Berlin, 10115 Berlin, Germany \\ 3 CAS Key Laboratory of Biogeography and Bioresource in Arid Land, Xinjiang Institute of Ecology and \\ Geography, Urumqi 830011, China \\ 4 Leibniz Institute of Ecological Urban and Regional Development, 01217 Dresden, Germany \\ 5 Faculty of Environmental Sciences, Technical University of Dresden (TUD), 01062 Dresden, Germany \\ 6 Department of Soil Science and Plant Nutrition, College of Grassland, Resources and Environment, \\ Inner Mongolia Agricultural University, Hohhot 010010, China; houmudan@hotmail.com \\ * Correspondence: Hua.Ma@zalf.de
}

Received: 4 October 2019; Accepted: 15 November 2019; Published: 20 November 2019

\begin{abstract}
To investigate the interrelationships among biochar, soil nutrients, and soybean plant growth in more detail, the root nodulation response of soybean (Glycine max L.) to biochar application was analyzed in a field study. We further examined the biochar effect on soil phosphatase activity to elucidate the relationships among biochar, phosphatase activity, and plant phosphorus uptake. Soybean was planted in a sandy field wherein the biochar and irrigation conditions were considered the two treatment factors. In our result, irrigation increased the pod number and plant height by $20.7 \%$ and $11.1 \%$, respectively. Irrigation reduced the shoot and root dry matter content by $67.9 \%$ and $75.1 \%$, respectively. The nodule number increased by $37 \%$ due to biochar addition under irrigated conditions. The soil carbon concentration was elevated by $13.4 \%$ with biochar application under rainfed conditions. Acid phosphomonoesterase (APM) was increased by $21.8 \%$ in the biochar-incorporated plots under the irrigated condition. Principal component analysis and redundancy analysis suggested that biochar application enhanced the relationships between the nodule number and soil potassium and magnesium concentrations. The correlation between soil sulfur content and nodule number was eliminated by biochar application. APM activity was associated with higher shoot and root phosphorus content and shoot dry weight after biochar application.
\end{abstract}

Keywords: biochar; irrigation; phosphatase activity; soybean root nodulation; redundancy analysis

\section{Introduction}

Biochar is a carbon (C)-rich material with high chemical stability. Its condensed aromatic structure is considered the main component that is difficult to degrade. This stabilized $\mathrm{C}$ compound may increase soil $\mathrm{C}$ sequestration and reduce $\mathrm{CO}_{2}$ emissions [1,2]. However, biochar produced at low temperatures was reported to have a substantial proportion of nonaromatic $C$, which may be more prone to oxidation [3,4], that can be used by microorganisms as a $C$ source $[5,6]$. This will provide organic matter content and thus reduce chemical fertilizer application for a sustainable agrosystem. 
Nitrogen $(\mathrm{N})$ is an essential element for the synthesis of major biomolecules in plants [7]. Chemical $\mathrm{N}$ fertilizer application is a main approach to supplement crops with $\mathrm{N}$ in agricultural ecosystems; however, it may be at the cost of energy, labor, and environmental damage [8,9]. One sustainable $\mathrm{N}$ source is biological nitrogen fixation (BNF). The $\mathrm{N}$ fixed by soybean-rhizobium symbiosis can amount up to $450 \mathrm{~kg} \mathrm{ha}^{-1}$ [10]. Nevertheless, drought is a limiting factor on the nodulation and the growth of the host legume in sandy soil. Rhizobia can survive in arid fields, but their population is at its lowest under these conditions, which may reduce the efficacy of inoculation for the host legume [11]. The coexisting acidic and basic properties of the surface of biochar may influence the water holding capacity and ion retention of the soil [4]. In addition, the high porosity of biochar may provide a habitat for microorganisms that can decompose the organic matter on the biochar surface [12]. Accordingly, biochar was used as an inoculant carrier to enhance the rhizobium survival rate and the soybean nodulation rate $[13,14]$.

Sulfur (S) can be used as fertilizer in a soybean field to enhance BNF, nodulation and crop biomass $[15,16]$. It has been reported that the BNF responds to $S$ deficits even faster than to photosynthesis [16,17]. At the early stage of nodulation, nodule formation is affected by $S$ because the demand for $\mathrm{N}$ by legumes is altered by the $\mathrm{S}$ supply [16]. An increase in nodule numbers was observed in S-added soil by Anderson and Spencer (1950) [18], and in turn, an S deficit caused lower nodule formation in comparison to S-sufficient conditions [15]. In the nodules, an S-containing antioxidant named glutathione was highly correlated with nitrogenase activity and thus could regulate BNF [19]. During $\mathrm{N}_{2}$ fixation, $\mathrm{S}$ is an essential element involved in the formation of the nitrogenase complex (Fe-S), which is responsible for the $\mathrm{N}_{2}$ reduction process $[17,20]$. Overall, $\mathrm{S}$ uptake, assimilation, and metabolism are strongly associated with BNF [20,21].

Biochar, plant roots, and microorganisms interact through multifaceted reactions [4,22-24]. In these interactions, enzymes are reaction catalysts that maintain the nutrient dynamics and soil health [25]. For example, in the organic phosphorus $(\mathrm{P})$ mineralization process, acid and alkaline phosphatases are involved in phosphomonoester hydrolysis to release phosphate. These phosphatases are more sensitive to variations in soil $\mathrm{pH}$ than in the organic matter content [26,27]. Liming was observed to elevate the alkaline phosphatase activity due to the increasing soil $\mathrm{pH}$ [28]. However, in a number of experiments, the mechanisms behind the biochar effect on phosphatases has not been clarified, even though biochar can increase the soil $\mathrm{pH}$. Li et al. (2017) observed that biochar addition enhanced alkaline phosphatase activity [29-31]. Masto et al. (2013) reported that biochar increased acid phosphatase activity by $32 \%$ and alkaline phosphatase activity by $22.8 \%$ [12]. The enhancements were attributed to increased microbial abundance or microbial community by biochar application. On the other hand, no effect of biochar on phosphatase activity was found either [32,33], suggesting that the enzyme or its substrate was not absorbed by the biochar.

Actually, there is evidence of specific mechanisms among biochar and plant roots, and soil chemical and biochemical properties [34,35]; however, studies have rarely been performed under a natural field setting. When data are averaged, this process can eliminate the small differences caused by the conditions of each replication of the experiment, especially in field studies. Each replication can be seen as a single observation that has its own specificity and heterogeneity. A better experimental methodology or a more in-depth exploration of the data and analysis would be more ideal and precise. Therefore, this work uses a principal component analysis (PCA) and redundancy analysis (RDA) to (1) analyze the soybean plant growth response to irrigation and biochar addition, (2) investigate the root nodulation response to soil nutrients when biochar is added to soybean fields, and (3) examine the effects of irrigation and biochar on soil phosphatase activity. 


\section{Materials and Methods}

\subsection{Field Site and Design}

The biochar was derived from black cherry wood and produced at $450{ }^{\circ} \mathrm{C}$ for 9 days by a biochar company (Terra Anima $($ online shop). The particle size was less than $4 \mathrm{~mm}$. The biochar was characterized by $415 \mathrm{~g} \mathrm{~kg}^{-1}$ total $\mathrm{C}, 3.8 \mathrm{~g} \mathrm{~kg}^{-1}$ total $\mathrm{N}, 0.6 \mathrm{~g} \mathrm{~kg}^{-1}$ total S, $8893 \mathrm{mg} \mathrm{kg}^{-1} \mathrm{Ca}$, $1151 \mathrm{mg} \mathrm{kg}^{-1} \mathrm{~K}, 471 \mathrm{mg} \mathrm{kg}^{-1} \mathrm{Mg}, 326 \mathrm{mg} \mathrm{kg}^{-1} \mathrm{P}, 111 \mathrm{C}: \mathrm{N}$ ratio, $8.4 \mathrm{pH}\left(\mathrm{H}_{2} \mathrm{O}\right), 22.7 \mathrm{cmol}^{+} \mathrm{kg}^{-1}$ cation exchange capacity (CEC), and $400 \mathrm{~m}^{2} \mathrm{~g}^{-1}$ surface area. The field experiment was performed on a sandy soil (sand: $77 \%$, silt: $15 \%$, and clay: $8 \%$ ) at the Leibniz Centre for Agricultural Landscape Research (ZALF), Müncheberg, Germany $\left(52.52^{\circ} \mathrm{N}, 14.11^{\circ} \mathrm{E}\right)$ in 2016. Soil characteristics are as follows: $9.2 \mathrm{~g} \mathrm{~kg}^{-1}$ total C, $1.0 \mathrm{~g} \mathrm{~kg}^{-1}$ total $\mathrm{N}, 0.2 \mathrm{~g} \mathrm{~kg}^{-1}$ total S, $2103 \mathrm{mg} \mathrm{kg}^{-1} \mathrm{Ca}, 1080 \mathrm{mg} \mathrm{kg}^{-1} \mathrm{~K}, 954 \mathrm{mg} \mathrm{kg}^{-1} \mathrm{Mg}$, $419 \mathrm{mg} \mathrm{kg}^{-1} \mathrm{P}, 9.3 \mathrm{C}: \mathrm{N}$ ratio, $6.3 \mathrm{pH}\left(\mathrm{H}_{2} \mathrm{O}\right)$, and $4.9 \mathrm{cmol}^{+} \mathrm{kg}^{-1}$ cation exchange capacity (CEC). The field was laid out along a transect that consisted of 7 plots (row) in length and 4 plots (line) in width. The plot size was $4.0 \mathrm{~m} \times 3.3 \mathrm{~m}$, and the spacing between plots was $7.0 \mathrm{~m}$ along the transect. Each row included 4 treatments; therefore, the 7 rows were considered as 7 replications. The four treatments were randomly arranged along each row. The treatments were as follows: (a) $10 \mathrm{tha} \mathrm{h}^{-1}$ biochar application with irrigation, (b) $10 \mathrm{t} \mathrm{ha}^{-1}$ biochar application without irrigation, (c) no biochar application with irrigation, and (d) no biochar application without irrigation. $10 \mathrm{t} \mathrm{ha}^{-1}$ of biochar were applied in biochar-treated field plots and subsequently ploughed into $15 \mathrm{~cm}$ soil depth before sowing. The dose of biochar referred to several previous field research studies [36,37]. Soybean (Glycine max L. var. sultana), which was purchased from the company BASF Services Europe, was planted in 8 rows in each plot. The spacing between rows was $35 \mathrm{~cm}$, and the seeding rate was 80 seeds $\mathrm{m}^{-2}$. The seeds were inoculated with Bradyrhizobium japonicum (HISTICK®Soy, BASF Services Europe Inc., Berlin, Germany) at a rate of $2 \times 10^{9} \mathrm{CFU} / \mathrm{g}$ before planting. The irrigation amount was calculated by the decision support system "Irrigama", developed at ZALF (Mirschel and Wenkel, 2004; Wenkel et al., 1988; Wenkel, 2011), which was based on a model that was calculated according to the climate, soil quality, and development stage of the plants. The calculation was based on primary data measured and evaluated in Müncheberg. Irrigation water was provided for four days to two lines of plots (11 July, 19 July, 22 July, and 25 July) and amounted to $75 \mathrm{~mm}$ in total. The other two lines of plots were not irrigated. In addition, $100 \mathrm{~kg} \mathrm{ha}^{-1}\left(46 \mathrm{~kg} \mathrm{P}_{2} \mathrm{O}_{5} \mathrm{ha}^{-1}\right)$ triple superphosphate fertilizer was applied to all plots. Considering the sandy, nutrient-poor soil at our field study site (sand: $77 \%$, silt: $15 \%$, and clay: $8 \%$ ), an amendment of $100 \mathrm{~kg} \mathrm{ha}^{-1}\left(46 \mathrm{~kg} \mathrm{P}_{2} \mathrm{O}_{5} \mathrm{ha}^{-1}\right)$ triple superphosphate fertilizer was supplied for nutrient compensation, according to other long-term field experiments in our region [38]. Furthermore, lime was supplied according to local practice in an amount of $2000 \mathrm{~kg} \mathrm{ha}^{-1}$ to all plots in order to stabilize soil $\mathrm{pH}$ at 6.26 [38]. The average temperature was $19.0^{\circ} \mathrm{C}$ during the crop season, the precipitation was $450.9 \mathrm{~mm}$, falling from May 12 to September 15.

\subsection{Measurements of Plant Dry Mass and Nutrient Concentrations}

Fifteen plants were sampled from four representative points in each plot 90 days after planting. The whole plant was carefully removed from the soil. The shoots and roots were separated, and then the roots were stored at $4{ }^{\circ} \mathrm{C}$ for nodule collection. The roots were washed with tap water and air-dried after the nodules were collected. Subsequently, all plant samples were moved to an oven and dried at $68^{\circ} \mathrm{C}$ for $48 \mathrm{~h}$. The samples were crushed by a mill equipped with a $1 \mathrm{~mm}$ screen after the dry weight was measured. The shoot and root dry matter contents were subsequently calculated. The crushed sample powder was prepared for the determination of plant $\mathrm{N}, \mathrm{P}$, and potassium (K) concentrations. The N, P, and $\mathrm{K}$ concentrations were determined by an inductively coupled plasma optical emission spectrometer (ICP-OES; iCAP 6300 Duo). 


\subsection{Measurements of the Plant Growth Parameters and Yield Components}

Twelve plants were selected for nondestructive measurements from four representative positions in each plot before harvesting. Three plants were selected from each position. The sampling positions were evenly spread out in the plot to minimize field heterogeneity. Growth parameters and yield data related to the plant cohorts were collected. The nondestructive measurements included the plant heights measured to the tip of the apical meristem and the number of pods, which were counted from the same plants that were used for the plant height measurements. Five of the eight rows were harvested for the yield calculation and thousand-seed weights.

\subsection{Nodule Sampling and Leghemoglobin Content Analysis}

After the roots (collected for root biomass in 2.3) were washed with tap water, the nodules were removed from the roots and counted. Then, the nodules were stored until the leghemoglobin $(\mathrm{Lb})$ content analysis was performed. The Lb content was analyzed by a protocol that followed the methods described by Wilson and Reisenauer (1963) [39]. In brief, $0.5 \mathrm{mg}$ of nodule tissue was ground with a mortar, and the thick liquid from the nodule tissue was moved to a $10 \mathrm{~mL}$ tube. The mortar was rinsed three times with $3 \mathrm{~mL}$ of Drabkin's solution. The tube was centrifuged at $500 \times g$ for $15 \mathrm{~min}$. The nodule tissue was extracted twice more with $3 \mathrm{~mL}$ of Drabkin's solution. The supernatants were combined, and the volume was adjusted to $10 \mathrm{~mL}$ with Drabkin's solution. Then, the mixture was shaken and centrifuged at $20,000 \times g$ for $30 \mathrm{~min}$. The analysis was standardized with a freshly prepared solution of bovine hemoglobin.

\subsection{Soil Analyses}

For soil sampling, the plant roots were carefully removed from 0 to $15 \mathrm{~cm}$ in depth, and then the rhizosphere soil was collected. The total carbon $(\mathrm{Ct})$, nitrogen $(\mathrm{Nt})$, and sulfur $(\mathrm{St})$ contents were measured by the dry combustion method [40], using an elemental determinator (TruSpec CNS). P, K, magnesium (Mg), and calcium (Ca) were determined with an ICP-OES (iCAP 6300 Duo). The CEC was determined using the method ISO 13536:1995 by ICP-OES (iCAP 6300 Duo) [41].

\subsection{Acid and Alkaline Phosphomonoesterase Activity Assays}

Moist soil $(0.5 \mathrm{~g}$ ) was placed in a $15 \mathrm{~mL}$ vial, and $2 \mathrm{~mL}$ of MUB buffer (pH 6.5 for the acid phosphatase assay or $\mathrm{pH} 11$ for the alkaline phosphatase assay) and $0.5 \mathrm{~mL}$ of p-nitrophenyl phosphate substrate solution $(0.05 \mathrm{M})$ were added to the vial sequentially. The assay and control batches were replicated 3 times. The soil suspension was incubated in a water bath at $37^{\circ} \mathrm{C}$, and after the vial was capped, the vial was shaken at $300 \mathrm{rpm}$. After $1 \mathrm{~h}$ of incubation, the vial was removed from the water bath and $2 \mathrm{~mL}$ of $\mathrm{NaOH}(0.5 \mathrm{M}), 0.5 \mathrm{~mL}$ of $\mathrm{CaCl}_{2}(0.5 \mathrm{M})$, and $5 \mathrm{~mL}$ of distilled water were subsequently added to cease the reaction. One milliliter of the soil suspension was centrifuged at $6500 \mathrm{rpm}$ for $5 \mathrm{~min}$. The color intensity of the supernatant was measured at $410 \mathrm{~nm}$ in a spectrophotometer. A calibration standard curve was obtained with five standard solutions containing $0,10,20,30,40$, and $50 \mu \mathrm{g}$ of p-nitrophenol. The controls were assayed following the same procedure, but the substrate was added after the addition of $\mathrm{NaOH}, \mathrm{CaCl}_{2}$, and distilled water [26].

\subsection{Statistical Analysis}

All data were subjected to the general linear model procedure to analyze the variance. The significance between treatments was tested with LSR at the $p<0.05$ level. These analyses were performed with SPSS 22 (IBM Deutschland GmbH, Ehningen, Germany). A principal component analysis was conducted to determine the correlations between the variables in Python 3.6.5. A biplot was utilized to visualize the results of the PCA. However, the PCA could not easily explain the multivariate response data. A redundancy analysis was used to clarify the dependent relationships between the explanatory variables (soil properties) and response variables (crop parameters) in $R$ 
3.5.1. The RDA used multiple linear regressions by allowing the regression of multiple response variables on multiple explanatory variables. The results of the RDA were shown on a triplot, on which the angles between arrows of the response and explanatory variables denote correlations; however, the angles between arrows of the explanatory variables may not be accurate enough to explain the correlations [42].

\section{Results}

\subsection{Plant Growth Parameters and Soybean Yield Components}

The plant dry matter and plant nutrient concentrations were not significantly affected by the biochar amendment 90 days after planting. While shoot dry matter weight increased significantly due to irrigation from $616-625 \mathrm{~g} \mathrm{~m}^{-2}$ to $694-697 \mathrm{~g} \mathrm{~m}^{-2}$, there were no significant differences for the root and seed dry weights. The shoot and root dry matter contents were reduced by irrigation from 26.7 and $67.9 \%$ to 30.4 and $75.1 \%$, respectively. The plant shoot $\mathrm{N}$ and $\mathrm{P}$ concentrations, root $\mathrm{N}$ and $\mathrm{P}$ concentrations, and shoot dry matter were significantly increased by $8.6 \%, 15.0 \%, 18.1 \%$, $55.4 \%$, and $12.1 \%$ with irrigation in comparison to those with the rainfed treatment, respectively. The soybean grain yield was not significantly increased by irrigation or biochar application. It ranged from $2.57 \mathrm{tha}^{-1}$ to $2.75 \mathrm{t} \mathrm{ha}^{-1}$ in all treatments (Table 1 ).

Table 1. Plant growth parameters and nutrient concentrations under treatment of biochar and/or irrigation in field trail.

\begin{tabular}{|c|c|c|c|c|c|}
\hline Plant Measures & $\begin{array}{l}\text { Shoot Dry } \\
\text { Weight } \\
\left(\mathrm{g} \mathrm{m}^{-2}\right)\end{array}$ & $\begin{array}{l}\text { Root Dry } \\
\text { Weight } \\
\left(\mathrm{g} \mathrm{m}^{-2}\right)\end{array}$ & $\begin{array}{l}\text { Grain Yield } \\
\quad\left(\mathrm{t} \mathrm{ha}^{-1}\right)\end{array}$ & $\begin{array}{c}\text { Shoot Dry } \\
\text { Matter } \\
\text { Content }(\%)\end{array}$ & $\begin{array}{c}\text { Root Dry } \\
\text { Matter } \\
\text { Content }(\%)\end{array}$ \\
\hline Irrigation + biochar & $694 \pm 17 a$ & $70 \pm 2 a$ & $2.85 \pm 0.24 \mathrm{a}$ & $26.96 \pm 0.37 b$ & $67.08 \pm 1.23 b$ \\
\hline Irrigation - biochar & $697 \pm 17 a$ & $71 \pm 3 a$ & $2.72 \pm 0.12 \mathrm{a}$ & $26.52 \pm 0.27 b$ & $68.60 \pm 2.35 b$ \\
\hline Rainfed + biochar & $616 \pm 14 b$ & $66 \pm 3 a$ & $2.59 \pm 0.09 a$ & $30.49 \pm 0.32 \mathrm{a}$ & $74.83 \pm 1.63 \mathrm{a}$ \\
\hline Rainfed - biochar & $625 \pm 10 b$ & $68 \pm 3 a$ & $2.55 \pm 0.10 \mathrm{a}$ & $30.39 \pm 0.41 \mathrm{a}$ & $75.29 \pm 1.41 \mathrm{a}$ \\
\hline \multirow{2}{*}{$\begin{array}{l}\text { Plant Nutrient } \\
\text { Concentration }\end{array}$} & \multicolumn{4}{|c|}{ Shoot } & \\
\hline & $N\left(g_{k g}{ }^{-1}\right)$ & $P\left(g_{k g}^{-1}\right)$ & $K\left(\mathrm{~g} \mathrm{~kg}^{-1}\right)$ & $M g\left(g_{k g}^{-1}\right)$ & \\
\hline Irrigation + biochar & $23.69 \pm 0.69 \mathrm{a}$ & $3.51 \pm 0.08 \mathrm{a}$ & $20.92 \pm 0.32 a$ & $3.38 \pm 0.09 a$ & \\
\hline Irrigation - biochar & $23.21 \pm 0.85 \mathrm{a}$ & $3.53 \pm 0.04 \mathrm{a}$ & $21.42 \pm 0.58 \mathrm{a}$ & $3.61 \pm 0.05 a$ & \\
\hline Rainfed + biochar & $21.68 \pm 0.25 b$ & $3.06 \pm 0.05 b$ & $20.80 \pm 0.20 \mathrm{a}$ & $3.69 \pm 0.09 a$ & \\
\hline Rainfed - biochar & $21.49 \pm 0.35 b$ & $3.06 \pm 0.12 b$ & $20.45 \pm 0.20 \mathrm{a}$ & $3.66 \pm 0.10 \mathrm{a}$ & \\
\hline \multirow{2}{*}{$\begin{array}{l}\text { Plant Nutrient } \\
\text { Concentration }\end{array}$} & \multicolumn{4}{|c|}{ Root } & \\
\hline & $\mathrm{N}\left(\mathrm{g} \mathrm{kg}^{-1}\right)$ & $P\left(g_{k g}^{-1}\right)$ & $\mathrm{K}\left(\mathrm{g} \mathrm{kg}^{-1}\right)$ & $\operatorname{Mg}\left(\mathrm{g} \mathrm{kg}^{-1}\right)$ & \\
\hline Irrigation + biochar & $7.55 \pm 0.41 \mathrm{a}$ & $1.67 \pm 0.12 \mathrm{a}$ & $12.23 \pm 0.48 \mathrm{a}$ & $2.49 \pm 0.14 \mathrm{a}$ & \\
\hline Irrigation - biochar & $7.84 \pm 0.36 \mathrm{a}$ & $1.50 \pm 0.09 \mathrm{a}$ & $12.20 \pm 0.36 \mathrm{a}$ & $2.47 \pm 0.11 \mathrm{a}$ & \\
\hline Rainfed + biochar & $6.61 \pm 0.09 b$ & $1.04 \pm 0.03 b$ & $10.40 \pm 0.44 \mathrm{a}$ & $2.25 \pm 0.09 \mathrm{a}$ & \\
\hline Rainfed - biochar & $6.42 \pm 0.12 b$ & $1.00 \pm 0.04 b$ & $10.28 \pm 0.35 \mathrm{a}$ & $2.31 \pm 0.06 \mathrm{a}$ & \\
\hline
\end{tabular}

Data presented as mean \pm SE. Data were compared among treatments and control using the Duncan test at $p<0.05$. The significance of difference indicated by different letter.

The rainfed plots showed $6.6 \%$ or $11 \mathrm{~g}$ higher values of thousand-seed weight than in the irrigated plots (Figure 1A). The plant height was enhanced significantly by irrigation from 85.4 to $94.9 \mathrm{~cm}$ by $11.1 \%$, whereas there was no significant effect from biochar application (Figure 1B). The irrigation effect was considered significant for the differences in soybean pod number between plots with and without irrigation. Irrigation significantly increased the pod number from 22.5 to 27.2 per plant, which was by 20.7\% (Figure 1C). 


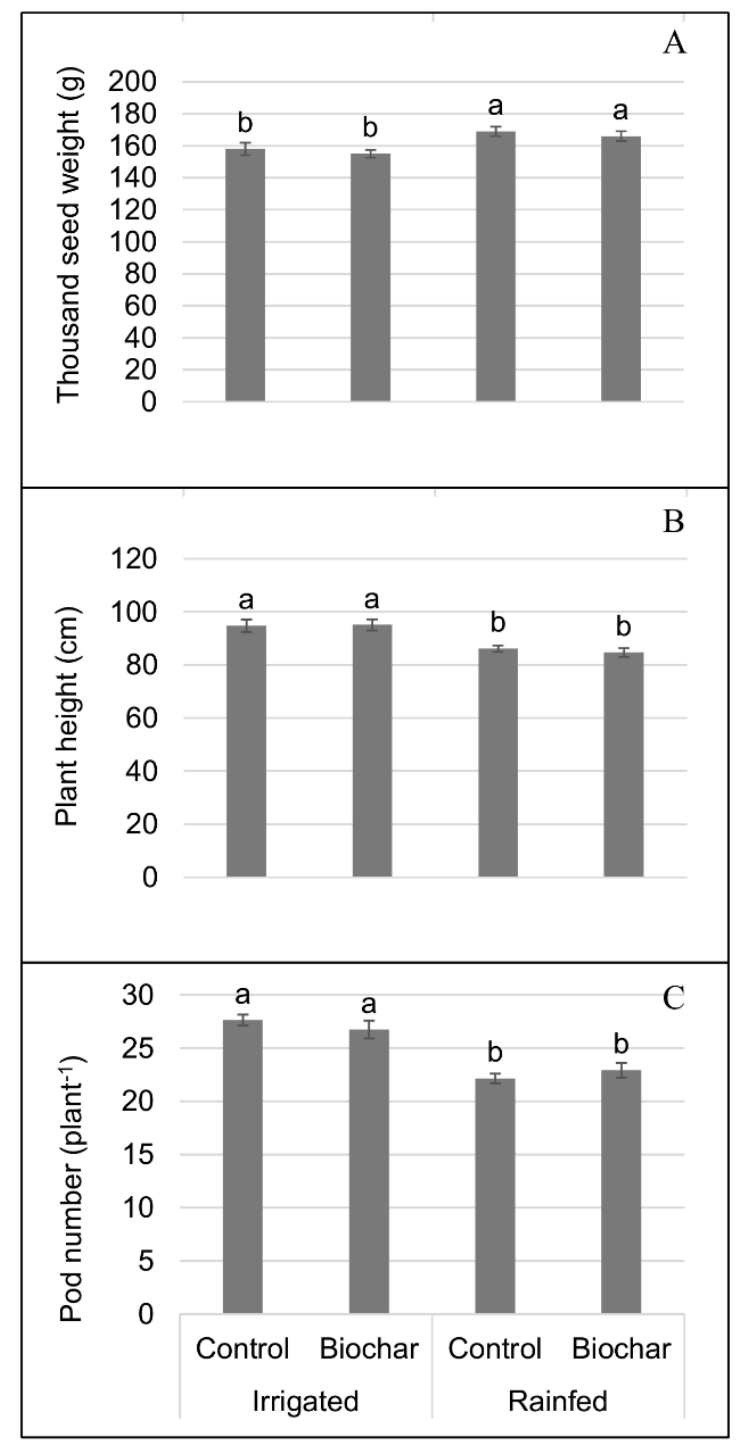

Figure 1. Effects of biochar and irrigation on thousand-seed weight, plant height, and pod number of soybean. Error bars (standard error) followed by a different letter within each column are significantly different at $p<0.05$ using the Duncan test.

\subsection{Nodulation, Lb Content, and Phosphatase Activity}

The number of nodules was 25.9 and 35.5 per plant for the control and biochar-amended plots under the irrigated conditions, respectively, and the number of nodules significantly increased by $37.0 \%$ with biochar application (Table 2). However, the nodule number, ranging from 12 to 17 per plant, was not significantly affected by biochar application under rainfed conditions. Irrigation enhanced the nodule number by $107.1 \%$ in comparison to that of the rainfed treatment, which ranged from 12-17 to 26-35 per plant. The Lb content did not vary with biochar addition under either the irrigated or the rainfed conditions. No significant increase in alkaline phosphomono-esterase (AKP) activity was observed with the biochar or irrigation treatments. Irrigation increased acid phosphomonoesterase (APM) from 6.13 to $7.47 \mu \mathrm{mol} \mathrm{pNP} \mathrm{g}^{-1} \mathrm{~h}^{-1}$ by $21.8 \%$ in the biochar-incorporated plots, whereas no effect was observed in the control treatment. 
Table 2. Nodule number, leghemoglobin content, soil enzyme activities, and soil water content under biochar and/or irrigation treatment in a field trial.

\begin{tabular}{cccccc}
\hline & Nodule Number & Lb Content & AKP Activity & APM Activity & $\begin{array}{c}\text { Soil Water } \\
\text { Content }\end{array}$ \\
\hline Unit & plant $^{-1}$ & $\mathrm{mg} \mathrm{gFW}^{-1}$ & $\mu \mathrm{mol} \mathrm{pNP} \mathrm{g}^{-1} \mathrm{~h}^{-1}$ & $\mu \mathrm{mol} \mathrm{pNP} \mathrm{g} \mathrm{h}^{-1}$ & $\%$ \\
\hline Irrigation + biochar & $35.46 \pm 4.32 \mathrm{a}$ & $70 \pm 2 \mathrm{a}$ & $3.19 \pm 0.89 \mathrm{a}$ & $7.47 \pm 0.42 \mathrm{a}$ & $6.9 \pm 0.8 \mathrm{a}$ \\
Irrigation - biochar & $25.88 \pm 3.61 \mathrm{~b}$ & $71 \pm 3 \mathrm{a}$ & $2.67 \pm 0.72 \mathrm{a}$ & $7.15 \pm 0.52 \mathrm{ab}$ & $6.3 \pm 0.7 \mathrm{a}$ \\
Rainfed + biochar & $17.38 \pm 3.97 \mathrm{c}$ & $66 \pm 3 \mathrm{a}$ & $2.70 \pm 0.36 \mathrm{a}$ & $6.13 \pm 0.40 \mathrm{~b}$ & $6.5 \pm 0.5 \mathrm{a}$ \\
Rainfed - biochar & $12.24 \pm 1.28 \mathrm{c}$ & $68 \pm 3 \mathrm{a}$ & $2.82 \pm 0.46 \mathrm{a}$ & $5.97 \pm 0.22 \mathrm{~b}$ & $5.8 \pm 0.5 \mathrm{a}$ \\
\hline
\end{tabular}

\subsection{Soil Chemical Properties}

The soil total $\mathrm{C}$ content was significantly increased by $13.4 \%$ with biochar application under the rainfed conditions, however, the effect was not observed under irrigated conditions (Table 3). The soil $\mathrm{P}$ content was slightly decreased by $4 \%$ with irrigation, but the difference was not significant. The soil $\mathrm{K}$ and $\mathrm{Mg}$ contents increased by 3\% and 7\% with irrigation, respectively, but the differences were not significant. Soil N, S, Ca, CEC, and pH were not significantly enhanced by biochar or irrigation

Table 3. Soil chemical properties under treatment of biochar and/or irrigation in field trail.

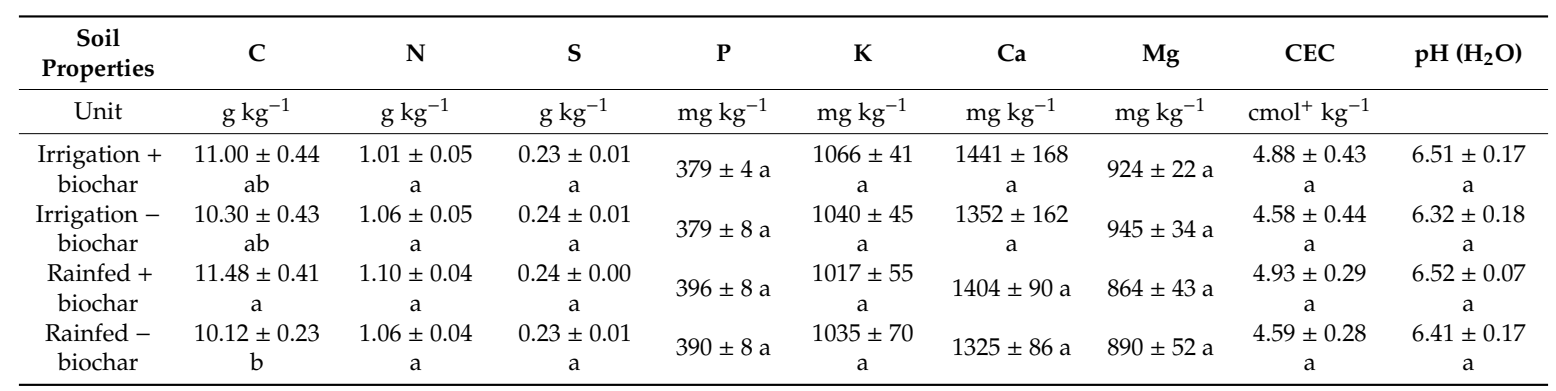

Data presented as mean \pm SE. Data were compared among treatments and control using the Duncan test at $p<0.05$. The significance of difference indicated by different letter.

\subsection{Principal Component Analysis}

Before the PCA was conducted, the feature weights were computed to show the contribution of the variables to the principal component (PC). The six PCs explained 35.0\%, 21.6\%, 12.6\%, 10.3\%, 7.0\%, and $5.7 \%$ of the total variance for the biochar-incorporated soil, and $41.4 \%, 18.7 \%, 15.5 \%, 9.9 \%, 5.8 \%$, and $3.5 \%$ of the total variance for the control soil, respectively. For the biochar treatments, soil St, Ca, CEC, and AKP were highly positively correlated with PC1, and APM was negatively correlated with PC1 (Figure 2A). Nodule number and soil $\mathrm{K}$ and $\mathrm{Mg}$ were negatively correlated with PC2. Without biochar amendment, soil CEC, AKP, and Ca were highly correlated with PC1, whereas the Lb content was negatively correlated with PC2 (Figure 2B). 


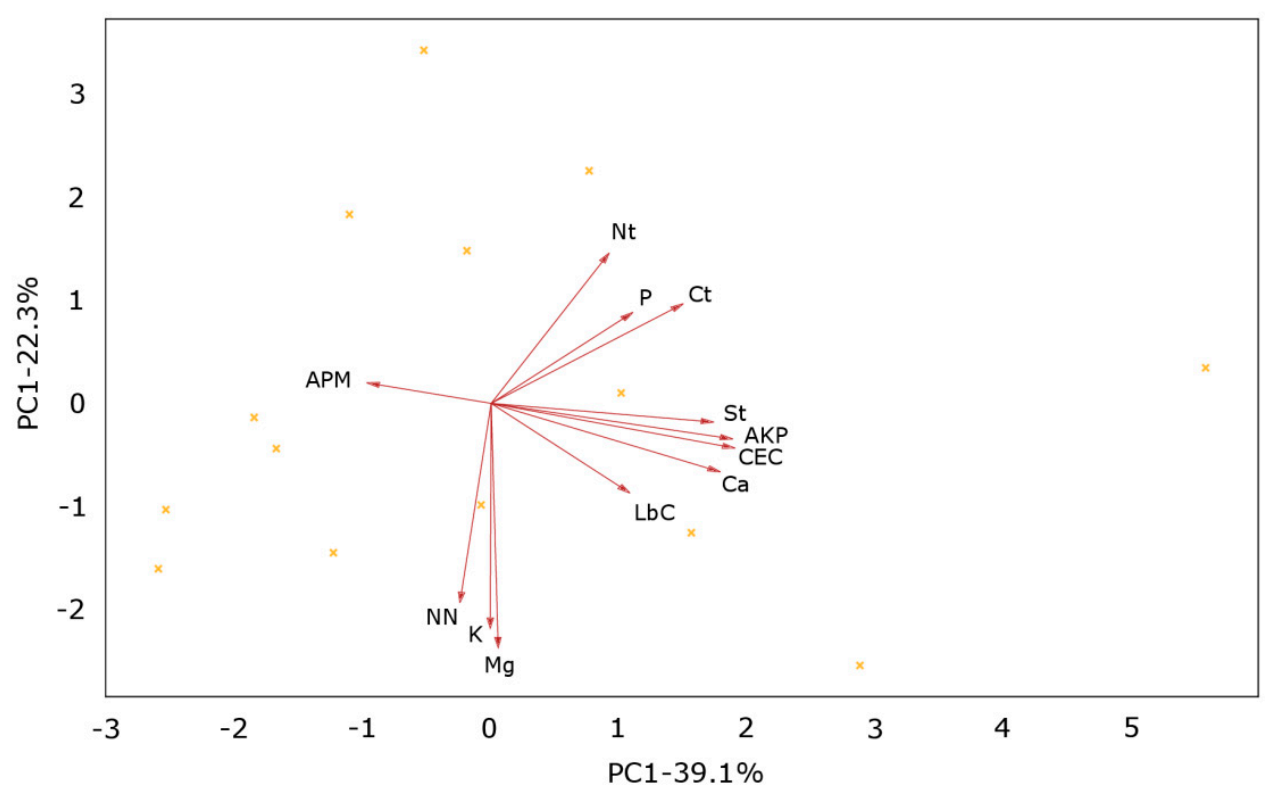

(A)

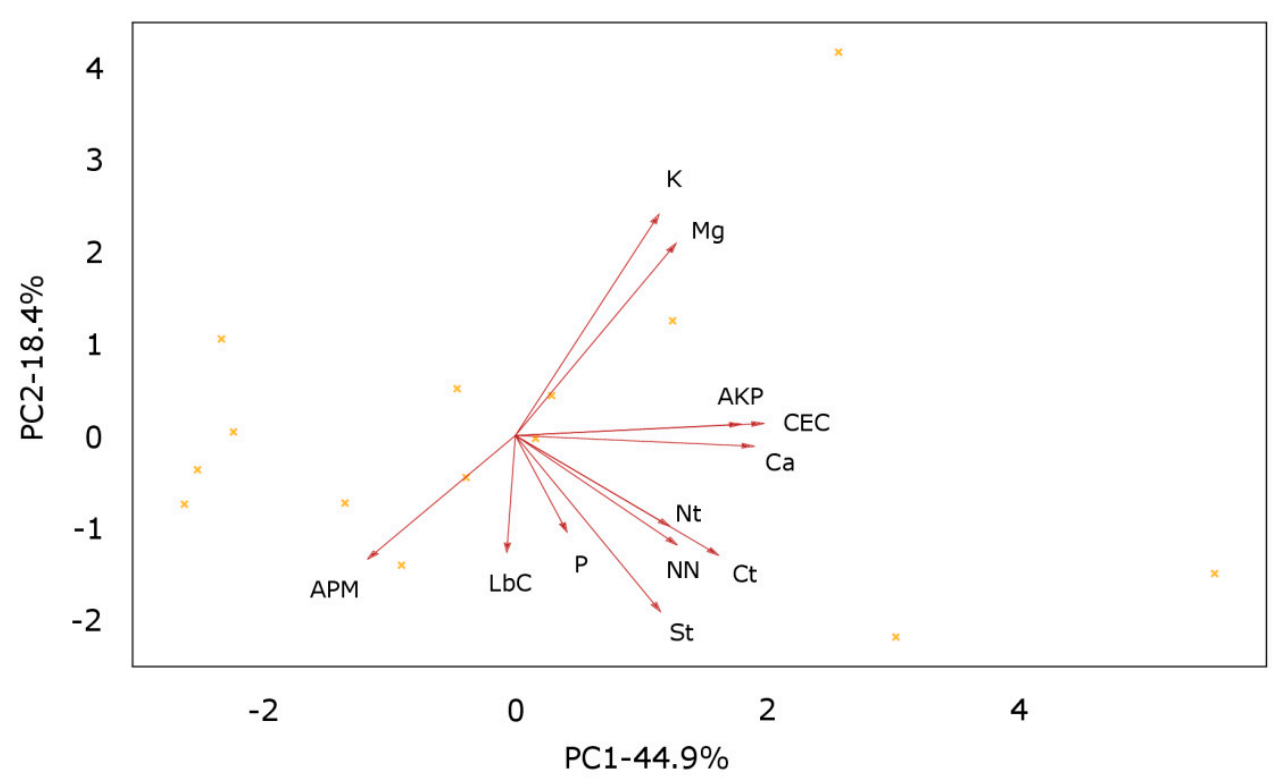

(B)

Figure 2. Principal component analysis (PCA)-ordination biplot of the first two components showing the PCA of variables in biochar-amended soil (A) and no biochar soil (B). APM: Acid phosphomonoesterase, AKP: Acid phosphomonoesterase, Ct: Total C content, LbC: Leghemoglobin content, NN: Nodule number, Nt: Total N content, St: Total S content.

The high contribution of $\mathrm{Nt}$ and nodule number to PC1 for the control soil changed to PC2 for the biochar-incorporated soil. $\mathrm{K}$ and $\mathrm{Mg}$ changed from being positively correlated with PC2 for the control soil to being negatively correlated with PC2 for the biochar-amended soil. The contribution of St to PC1 was enhanced in the biochar-incorporated soil in comparison to that in the control soil. This result indicated that $\mathrm{Nt}, \mathrm{K}, \mathrm{Mg}$, St, and nodule number were altered following biochar incorporation. The loading values of $\mathrm{CEC}, \mathrm{AKP}$, and $\mathrm{Ca}$ on $\mathrm{PC} 1$ were consistently high for both soils. 


\subsection{Redundancy Analysis}

The data from the response variables (yield, nodule number, shoot $\mathrm{N}$, shoot $\mathrm{K}$, shoot $\mathrm{P}$, shoot $\mathrm{Mg}$, $\operatorname{root} \mathrm{N}$, root $\mathrm{K}$, root $\mathrm{P}$, and root $\mathrm{Mg}$ ) were standardized before the RDA was performed. The first six RDAs explained $36.4 \%, 22.4 \%, 15.8 \%, 9.4 \%, 6.1 \%$, and $4.0 \%$ of the total variance in the crop and nodule parameters for the biochar-incorporated soil data and explained $41.0 \%, 25.6 \%, 13.3 \%, 7.7 \%$, $4.4 \%, 3.6 \%$, and $2.5 \%$ of the total variance in the crop and nodule parameters for the control soil. The biochar-treated soil showed that (Figure 3A): (1) Crop yield, root dry weight, and root Mg were positively correlated with AKP, (2) nodule number, root $\mathrm{P}$, shoot dry weight, and shoot $\mathrm{P}$ were positively correlated with APM, (3) root $\mathrm{K}$ and shoot $\mathrm{N}$ were negatively correlated with $\mathrm{Nt}$, and (4) shoot $\mathrm{K}$ was negatively correlated with the Lb content, St, and CEC. The control soil showed that (Figure 3B): (1) Crop yield, shoot dry weight, shoot $N$, and root $K$ were positively correlated with APM and the Lb content, but negatively correlated with $\mathrm{P}$, (2) shoot $\mathrm{K}$ was negatively correlated with $\mathrm{P},(3)$ shoot $\mathrm{Mg}$ was negatively correlated with $\mathrm{Ct}, \mathrm{St}, \mathrm{Ca}, \mathrm{CEC}$, and $\mathrm{AKP}$, and (4) root dry weight was positively correlated with $\mathrm{Ct}, \mathrm{Ca}, \mathrm{CEC}$, and $\mathrm{AKP}$, whereas root $\mathrm{Mg}$ was negatively correlated with $\mathrm{Ct}$ and $\mathrm{St}$.

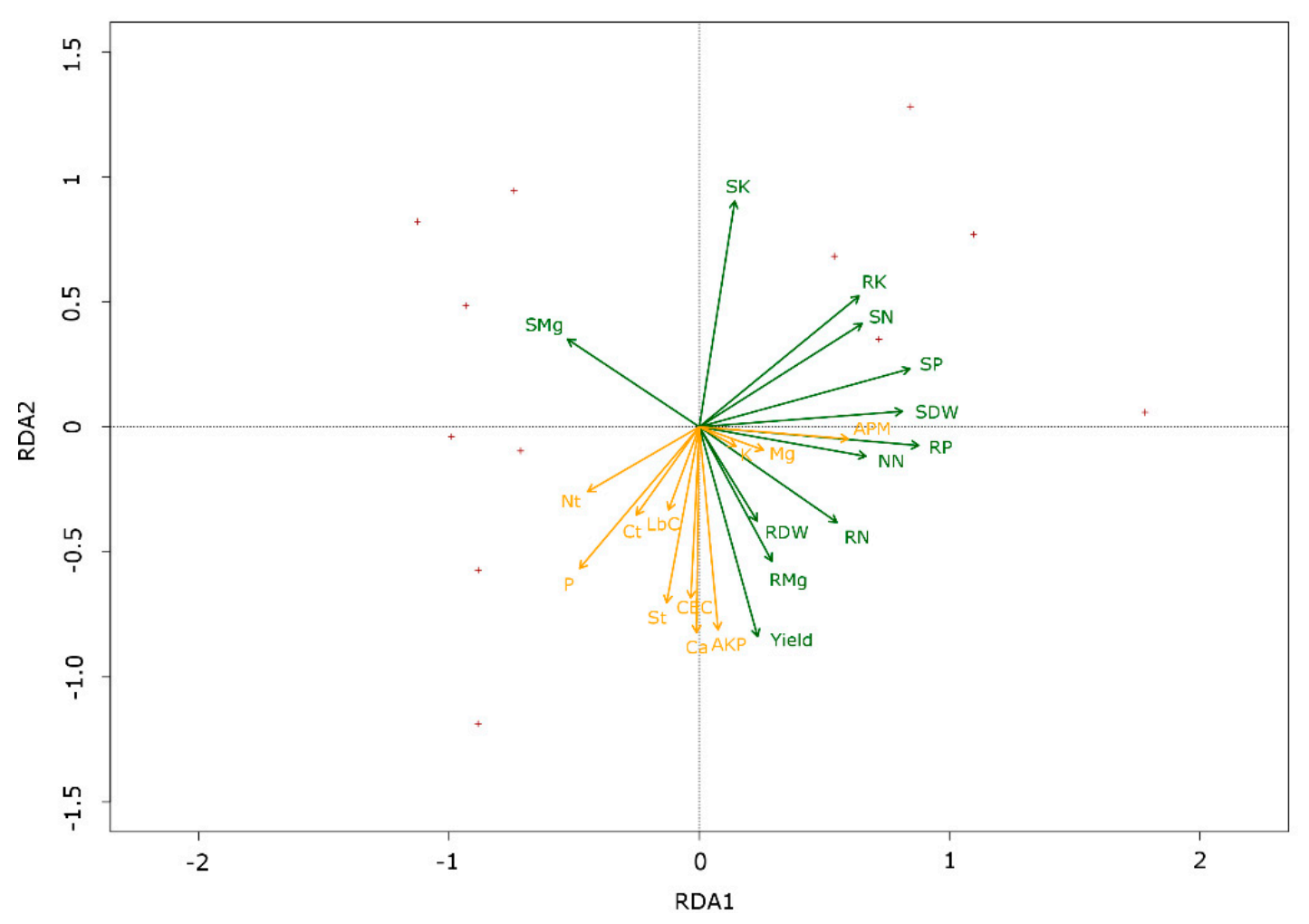

(A)

Figure 3. Cont. 


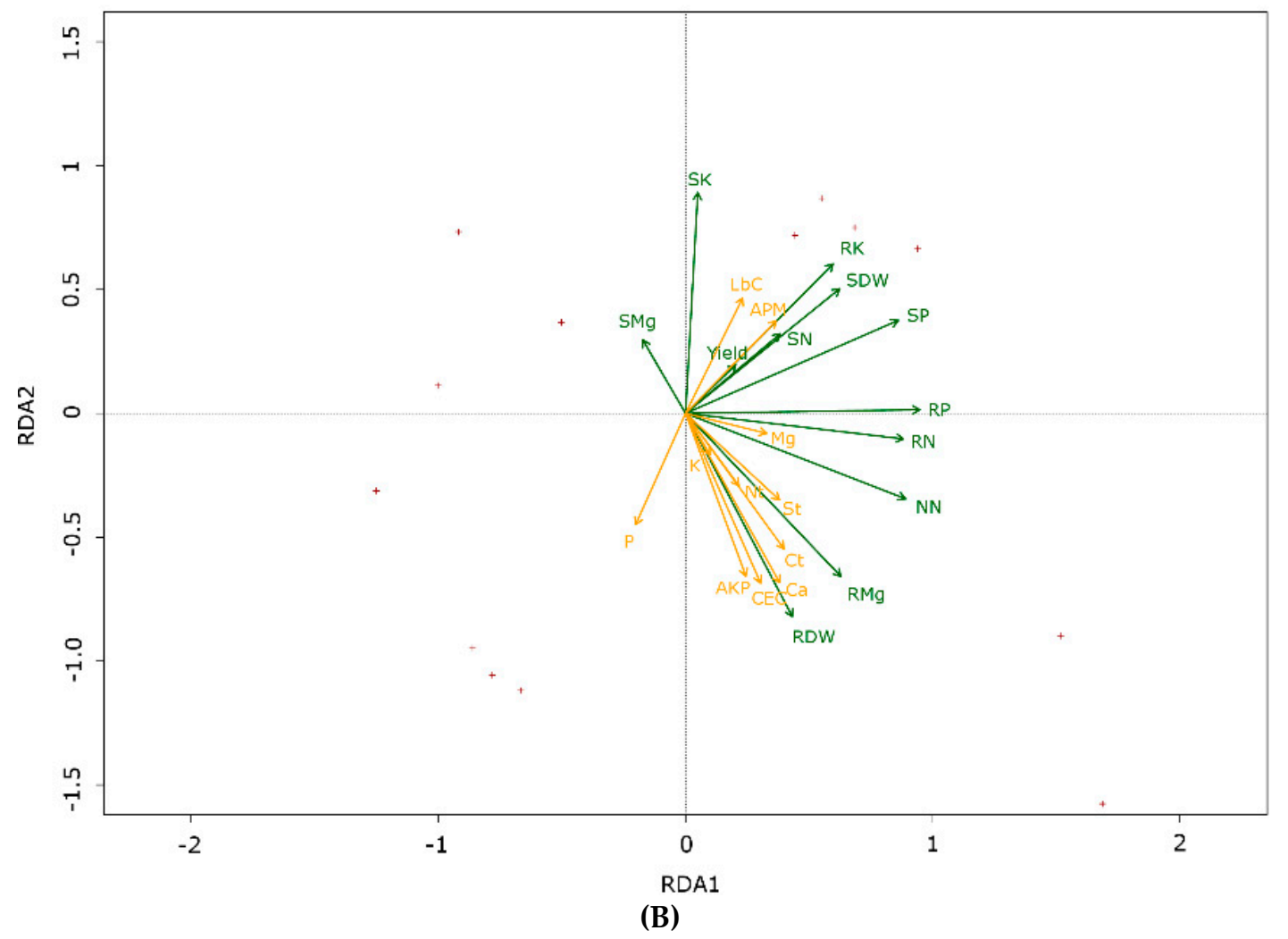

Figure 3. RDA-ordination triplot of variables in biochar-amended soil (A) and no biochar soil (B). Response variables are shown by the green arrow; explanatory variables are shown by the yellow arrow. RDW: Root dry weight, RK: Root K content, RMg: Root Mg content, RN: Root N, RP: Root P, SDW: Shoot dry weight, SK: Shoot K content, SMg: Shoot Mg content, SN: Shoot N, SP: Shoot P.

\section{Discussion}

\subsection{Plant Growth Response to Irrigation and Biochar Addition}

The plant height and pod number increased with irrigation, whereas the thousand-seed weight decreased significantly, and the grain yield was not significantly enhanced. It has been proven that shoot competition may have effects on reproduction because the reproductive structures were found in the shoots. Meristem allocation is influenced by shoot competition $[43,44]$. Plants normally increase their height at the cost of lateral growth when under adequate water conditions $[45,46]$. As a consequence, the branch number will also be decreased [47], which may decrease the potential of plants to produce meristems for reproduction. Accordingly, a greater plant height and pod number was accompanied by a lower thousand-seed weight, resulting in a uniform grain yield between the irrigated conditions and rainfed conditions. The increased plant growth was from more vegetative growth, but carbohydrate allocation to the seed was thus reduced.

In general, the dry matter contents of plants grown under water stress increase due to the higher accumulation of assimilates as plant metabolism or activation of stress responses require assimilates $[48,49]$. The higher plant biomass was accompanied by a greater plant water content and lower dry matter content. Carbohydrate accumulation occurs under drought stress conditions, e.g., sucrose and sugar alcohols [50,51]. Both the shoot and root dry matter contents were enhanced by irrigation in the current study. The dry weight of plants has been widely reported to be increased by biochar application [35,52,53], and biochar has also been found not to increase plant dry weight [17]. However, there is a lack of research concerning the biochar effect on the dry matter content of plants. In our study, the enhanced correlations between the shoot dry matter content and shoot N, root N, and root $\mathrm{Mg}$ by biochar application is likely due to the promoting effect of biochar on nodulation. Biochar 
also enhanced the correlation between the root dry matter content and APM activity. Biochar showed the potential to affect $\mathrm{P}$ uptake as shoot dry matter content and APM activity had a strong correlation with shoot $\mathrm{P}$, root $\mathrm{P}$, and shoot dry weight under the biochar treatment.

\subsection{Biochar Influence on Soil C}

Biochar is a C-rich solid material obtained from thermochemical conversion of biomass in an oxygen-limited environment and mainly consists of two forms, as aromatic and nonaromatic C. The condensed aromatic structure of biochar makes it commonly hard to degrade [4]. Novak et al. found that high pyrolysis temperature may contribute to a relatively low level of surface oxidation of the pecan shell biochar and, hence, the lack of a significant impact of biochar additions on CEC, and concluded that low-temperature biochars would most likely also increase soil C sequestration, but they would probably more rapidly change soil fertility characteristics when compared with using high-temperature biochars [54]. However, a biochar aging reaction is assumed after it is incorporated into the soil, and more detailed, chemical studies are required in this context. In the present study, the addition of biochar derived from black cherry wood (produced at $450{ }^{\circ} \mathrm{C}$ ) provided a significantly greater total $C$ content under rainfed conditions than that of the control, while the difference was not significant under the irrigated conditions. It is most likely, and the only conclusive statement for us unless results from more detailed studies would be available, that the dissolution and leaching of organic compounds from biochar are more readily available at the first stage of aging if the soil is under humid conditions $[4,55,56]$. Lastly, high loading values of the total C content on PC1 and PC2 implied that $C$ storage could potentially benefit from biochar application in sandy soil.

\subsection{Root Nodulation Response to Soil N, K, Mg, and S Based on Biochar Addition}

The nodule number showed the potential to enhance BNF via biochar application under irrigated conditions. This study further analyzed the leghemoglobin content of the nodules to determine whether the nodules were active in fixing N. Leghemoglobin, which is the most abundant protein in nodules, can bind oxygen with a low $\mathrm{K}_{\mathrm{m}}$ to reduce free oxygen, which may cause irreversible oxidation of nitrogenase $[57,58]$. However, leghemoglobin regulates the release of bound oxygen to bacteroids, which utilize oxygen for respiration and ATP production for $\mathrm{N}$ fixation $[59,60]$. The leghemoglobin content of the nodules was not significantly different among the treatments in our study. In addition, under the rainfed conditions, there was no difference in nodulation with biochar addition. It is very likely that the water deficit played a more crucial role in nodulation than did the beneficial effect of biochar under the examined rainfed conditions. Water deficits were reported to inhibit root hair infection by Rhizobium and the formation of infection threads [61-63].

Nodulation was also reported to be regulated by K and Mg in the soil. Several studies demonstrated that a higher $\mathrm{Mg}$ concentration elicited a greater nodule number in soybean plants [64] and that a $\mathrm{Mg}$ deficit induced poor nodulation in alfalfa (Medicago sativa) plants [65]. It was also stated that nodulation was inhibited under a low K supply shortly before the rhizobium invaded the root hairs $[35,66]$. However, there is a lack of information on the molecular mechanism of the effects of $\mathrm{K}$ and $\mathrm{Mg}$ on nodulation. In the PCA, nodule number was highly correlated with soil $\mathrm{K}$ and $\mathrm{Mg}$ under the biochar treatment. This result may be attributed to the fact that $\mathrm{K}$ and $\mathrm{Mg}$ availability increased when biochar was added to the soil $[6,35,66]$. S was reported to be crucial for both nodulation and BNF in legumes [20]. The $\mathrm{S}$ supply can also affect nodule formation because the demand for $\mathrm{N}$ by legumes varies with $\mathrm{S}$ supply [16]. It was observed that $S$ may increase nodule weight and number [18]. In our work, soil total $\mathrm{S}$ had a positive correlation with nodule number in the control soil, whereas no correlation between nodule number and soil total S was found in the biochar-applied soil in the PCA with high factor loading values. The result indicates that biochar application altered the interrelationship between soil total $\mathrm{S}$ and nodule formation. Few studies have demonstrated the effect of biochar on $\mathrm{S}$ transformation and availability. We hypothesize that the biochar promoting effect was dominant for nodulation and 
thus obscured the $\mathrm{S}$ effect because the $\mathrm{S}$ concentration in the soil was not at a low level during the soybean life spin $\left(0.23 \mathrm{~g} \mathrm{~kg}^{-1}\right.$ of $\left.\mathrm{S}\right)$. However, direct evidence is still needed to confirm this assumption.

\subsection{The Relationships Among Biochar, Phosphatase Activity, and Root P}

APM activity was greater under irrigated conditions than under rainfed conditions for the biochar treatment. Similar results showed that drought stress decreased soil acid phosphatase activity by $22-27 \%$, whereas the decrease was not observed for alkaline phosphatase activity during the cropping season [67]. The mechanism was attributed to a decrease in soil microbial populations by water stress. However, irrigation did not elevate APM activity for the control in our study. Presumably, biochar moderated drought stress when irrigation was implemented [68]. APM may be secreted by plants and also be derived from fungi and bacteria, whereas AKP is mainly derived from bacteria in the soil $[69,70]$. This fact supports the PCA and RDA results. The APM activity tended to be independent from the other soil properties except soil $\mathrm{K}$ and $\mathrm{Mg}$ in the control, while the biochar addition enhanced the independence of the AMP activity in the PCA.

To elucidate the correlations between the explanatory variables and response variables, which the PCA was not able to demonstrate, an RDA was performed. The APM activity had a strong correlation with shoot $\mathrm{P}$, root $\mathrm{P}$, and shoot dry weight under the biochar treatment in the RDA. It is likely that biochar affected the P uptake as biochar may increase organic P mineralization [12], facilitate the association between plants and mycorrhizal fungi, which may enhance $P$ uptake [71,72], and promote P-solubilizing microorganisms to release organic acid to solubilize ortho-P [73-75].

\subsection{Liming Effect on Soil CEC, Root Nodulation, and AKP Activity}

The high factor loading values of Ca, CEC, and AKP on the PCA both with and without the biochar-amended treatments indicate their strong correlation with one another and their large influence on the soil properties. This result was likely triggered by a liming effect due to the high application rate in the field. Liming was shown to enhance BNF [76] and promote nodulation for legumes grown in acidic soils due to an increase in soil $\mathrm{pH}$ [77]. In addition, $\mathrm{Ca}^{2+}$ is involved in the nodulation signaling pathways at the early stage of nodule formation [78,79]. Limestone is commonly applied to elevate the soil $\mathrm{pH}$ and it can also alter the CEC value [77]. $\mathrm{Ca}^{2+}$ may cause the release of negative charge by variable minerals, and in turn, the negative charge on the mineral surfaces causes the CEC to be elevated. Liming can also elevate phosphate availability by enhancing organic P mineralization in which AKP is involved in the catalysis [28,80]. It has been reported that AKP is more dependent on soil $\mathrm{pH}$ than on the organic matter content [26]. Therefore, AKP showed a strong correlation with $\mathrm{Ca}^{2+}$ due to the increased soil $\mathrm{pH}$ value from liming.

\section{Conclusions}

This study highlighted the complicated influences of irrigation and biochar application on soybean plant growth and nodulation and on soil phosphatase activities. Irrigation enhanced the pod number and plant height, while the thousand-seed weight was decreased. This result may be attributed to the fact that irrigation enhanced shoot growth, resulting in a competitive effect on reproduction. Biochar did not have a significant effect on the yield components and plant growth parameters. Nevertheless, we found that biochar enhanced the correlations among the plant growth parameters, yield components, plant nutrient contents, and soil enzyme activities. This result suggests that biochar may influence plant $\mathrm{N}$ and $\mathrm{P}$ uptake.

Biochar not only directly benefited soybean root nodulation, but also potentially enhanced the relationships between the nodule number and soil $\mathrm{K}$ and $\mathrm{Mg}$. In addition, the positive correlation between the soil $\mathrm{S}$ content and nodule number was eliminated with biochar application. Thus, the effects of biochar on root nodulation indicate that the mechanisms of biochar application are intricate and do not just involve a single process. 
An adequate water supply can maintain an ideal level of APM activity, which may further promote mineralization to enhance soybean plant growth as APM activity had a strong correlation with shoot $\mathrm{P}$, root $\mathrm{P}$, and shoot dry weight. APM activity was not significantly increased by biochar addition. AKP activity was not significantly enhanced by either biochar or irrigation but was influenced by liming.

In conclusion, water deficit is the first limiting factor in the sandy soil under study. If irrigation is feasible, biochar application in soybean fields may be a promising technique to help develop a balanced and productive crop cultivation system.

Author Contributions: Data curation, H.M.; Formal analysis, H.M.; Methodology, H.M., D.E., S.W., and S.D.B.-K.; Resources, D.E. and S.D.B.-K.; Supervision, D.E. and S.D.B.-K.; Writing—original draft, H.M.; Writing-review and editing, H.M., D.E., S.W., Q.L., R.A.O., M.H., and S.D.B.-K.

Acknowledgments: This work was funded by the Foundation Fiat Panis (Promotion of Research and Science to End Hunger in The World) and INNISOY project (Innovation Network to Improve Soybean Production under the Global Change), and by the Chinese Academy of Sciences President's International Fellowship Initiative (Grant No. 2018VBA002S) to DE. We thank all of our colleagues for their technical assistance during the field trial at the ZALF Research Station. We highly appreciate the support from Moritz Reckling and Gunhild Rosner from ZALF, who helped us planning and carrying out the field experiment.

Conflicts of Interest: The authors have no conflicts of interest.

\section{References}

1. Lanza, G.; Rebensburg, P.; Kern, J.; Lentzsch, P.; Wirth, S. Impact of Chars and Readily Available Carbon on Soil Microbial Respiration and Microbial Community Composition in a Dynamic Incubation Experiment. Soil Tillage Res. 2016, 164, 18-24. [CrossRef]

2. Smith, P.; Gregory, P.J. Climate Change and Sustainable Food Production. Proc. Nutr. Soc. 2013, 72, $21-28$. [CrossRef] [PubMed]

3. McBeath, A.V.; Smernik, R.J. Variation in the Degree of Aromatic Condensation of Chars. Org. Geochem. 2009, 40, 1161-1168. [CrossRef]

4. Joseph, S.D.; Camps-Arbestain, M.; Lin, Y.; Munroe, P.; Chia, C.H.; Hook, J.; van Zwieten, L.; Kimber, S.; Cowie, A.; Singh, B.P.; et al. An Investigation into the Reactions of Biochar in Soil. Aust. J. Soil Res. 2010, 48, 501-515. [CrossRef]

5. Boonchan, S.; Britz, M.L.; Stanley, G.A. Degradation and Mineralization of High Molecular Weight Polycyclic Armoatic Hydrocarbons by Defined Fungal Bacterial Cocultures. Appl. Environ. Microbiol. 2000, 66, 1007-1019. [CrossRef] [PubMed]

6. Lehmann, J.; Rillig, M.C.; Thies, J.; Masiello, C.A.; Hockaday, W.C.; Crowley, D. Biochar Effects on Soil Biota-A Review. Soil Biol. Biochem. 2011, 43, 1812-1836. [CrossRef]

7. Hagemann, N.; Harter, J.; Behrens, S. Elucidating the Impacts of Biochar Applications on Nitrogen Cycling Microbial Communities; Elsevier Inc.: Amsterdam, The Netherlands, 2016. [CrossRef]

8. Gong, H.; Meng, D.; Li, X.; Zhu, F. Soil Degradation and Food Security Coupled with Global Climate Change in Northeastern China. Chin. Geogr. Sci. 2013, 23, 562-573. [CrossRef]

9. Massah, J.; Azadegan, B. Effect of Chemical Fertilizers on Soil Compaction and Degradation. Agric. Mech. Asia Afr. Lat. Am. 2016, 47, 44-50.

10. Salvagiotti, F.; Cassman, K.G.; Weiss, A.; Dobermann, A. Nitrogen Uptake, Fixation and Response to N Fertilizer in Soybeans. Field Crops Res. 2008, 108, 1-13. [CrossRef]

11. Dwivedi, S.L.; Sahrawat, K.L.; Upadhyaya, H.D.; Mengoni, A.; Galardini, M.; Bazzicalupo, M.; Biondi, E.G.; Hungria, M.; Kaschuk, G.; Blair, M.W.; et al. Advances in Host Plant and Rhizobium Genomics to Enhance Symbiotic Nitrogen Fixation InGrain Legumes; Elsevier Ltd.: Amsterdam, The Netherlands, 2015; Volume 129. [CrossRef]

12. Masto, R.E.; Kumar, S.; Rout, T.K.; Sarkar, P.; George, J.; Ram, L.C. Biochar from Water Hyacinth (Eichornia Crassipes) and Its Impact on Soil Biological Activity. Catena 2013, 111, 64-71. [CrossRef]

13. Głodowska, M.; Schwinghamer, T.; Husk, B.; Smith, D. Biochar Based Inoculants Improve Soybean Growth and Nodulation. Agric. Sci. 2017, 8, 1048-1064. [CrossRef] 
14. Egamberdieva, D.; Jabborova, D.; Wirth, S.J.; Alam, P.; Alyemeni, M.N.; Ahmad, P. Interactive Effects of Nutrients and Bradyrhizobium Japonicum on the Growth and Root Architecture of Soybean (Glycine Max L.). Front. Microbiol. 2018, 9, 1000. [CrossRef] [PubMed]

15. Scherer, H.W. $\mathrm{N}_{2}$ Fixation and Growth of Legumes as Affected by Sulphur Fertilization. Biol. Fertil. Soils 1996, 23, 449-453. [CrossRef]

16. Scherer, H.W.; Pacyna, S.; Spoth, K.R.; Schulz, M. Low Levels of Ferredoxin, ATP and Leghemoglobin Contribute to Limited N2 Fixation of Peas (Pisum Sativum L.) and Alfalfa (Medicago Sativa L.) under S Deficiency Conditions. Biol. Fertil. Soils 2008, 44, 909-916. [CrossRef]

17. Scheifele, M.; Hobi, A.; Buegger, F.; Gattinger, A.; Schulin, R.; Boller, T.; Mäder, P. Impact of Pyrochar and Hydrochar on Soybean (Glycine Max L.) Root Nodulation and Biological Nitrogen Fixation. J. Plant Nutr. Soil Sci. 2017, 180, 199-211. [CrossRef]

18. Anderson, A.J.; Spencero, D. Molybdenum in nitrogen metabolism of legumes and non-legumes. Aust. J. Sci. Res. 1950, 3, 414-430. [CrossRef]

19. El Msehli, S.; Lambert, A.; Baldacci-Cresp, F.; Hopkins, J.; Boncompagni, E.; Smiti, S.A.; Hérouart, D.; Frendo, P. Crucial Role of (Homo)Glutathione in Nitrogen Fixation in Medicago Truncatula Nodules. New Phytol. 2011, 192, 496-506. [CrossRef]

20. Kalloniati, C.; Krompas, P.; Karalias, G.; Udvardi, M.K.; Rennenberg, H.; Herschbach, C.; Flemetakis, E. Nitrogen-Fixing Nodules Are an Important Source of Reduced Sulfur, Which Triggers Global Changes in Sulfur Metabolism in Lotus japonicus. Plant Cell 2015, 27, 2384-2400. [CrossRef]

21. Davidian, J.C.; Kopriva, S. Regulation of Sulfate Uptake and Assimilation-The Same or Not the Same? Mol. Plant 2010, 3, 314-325. [CrossRef]

22. Sorrenti, G.; Muzzi, E.; Toselli, M. Root growth dynamic and plant performance of nectarine trees amended with biochar and compost. Sci. Hortic. 2019, 257, 108710. [CrossRef]

23. Lu, H.; Li, Z.; Fu, S.; Mendez, A.; Gasco, G.; Paz-Ferreiro, J. Effect of Biochar in Cadmium Availability and Soil Biological Activity in an Anthrosol Following Acid Rain Deposition and Aging. Water Air Soil Pollut. 2015, 226, 164. [CrossRef]

24. Gascó, G.; Paz-Ferreiro, J.; Cely, P.; Plaza, C.; Méndez, A. Influence of pig manure and its biochar on soil $\mathrm{CO}_{2}$ emissions and soil enzymes. Ecol. Eng. 2016, 5, 19-24. [CrossRef]

25. Das, S.K.; Varma, A. Soil Enzymology. Sci. Prog. 2011, 64, 275-285. [CrossRef]

26. Acosta-Martínez, V.; Tabatabai, M.A. Phosphorus Cycle Enzymes. In Methods of Soil Enzymology; Dick, R.P., Ed.; SSSA Book Series, No. 9; Soil Science Society of America: Madison, WI, USA, 2011; pp. 161-183. [CrossRef]

27. Benavente, I.; Gasco, G.; Plaza, C.; Paz-Ferreiro, J.; Mendez, A. Choice of pyrolysis parameters for urban wastes affects soil enzymes and plant germination in a Mediterranean soil. Sci. Total Environ. 2018, 634, 1308-1314. [CrossRef] [PubMed]

28. Acosta-Martínez, V.; Tabatabai, M.A. Enzyme Activities in a Limed Agricultural Soil. Biol. Fertil. Soils 2000, 31, 85-91. [CrossRef]

29. Li, S.; Liang, C.; Shangguan, Z. Effects of Apple Branch Biochar on Soil C Mineralization and Nutrient Cycling under Two Levels of N. Sci. Total Environ. 2017, 607-608, 109-119. [CrossRef]

30. Paz-Ferreiro, J.; Fu, S. Biological indices for soil quality evaluation: Perspectives and limitations. Land Degrad. Dev. 2016, 27, 14-25. [CrossRef]

31. Foster, E.J.; Fogle, E.J.; Cotrufo, M.F. Sorption to biochar impacts $\beta$-glucosidase and phosphatase enzyme activities. Agriculture 2018, 8, 158. [CrossRef]

32. Abujabhah, I.S.; Bound, S.A.; Doyle, R.; Bowman, J.P. Effects of Biochar and Compost Amendments on Soil Physico-Chemical Properties and the Total Community within a Temperate Agricultural Soil. Appl. Soil Ecol. 2016, 98, 243-253. [CrossRef]

33. Elzobair, K.A.; Stromberger, M.E.; Ippolito, J.A. Stabilizing Effect of Biochar on Soil Extracellular Enzymes after a Denaturing Stress. Chemosphere 2016, 142, 114-119. [CrossRef]

34. Prendergast-Miller, M.T.; Duvall, M.; Sohi, S.P. Biochar-root interactions are mediated by biochar nutrient content and impacts on soil nutrient availability. Eur. J. Soil Sci. 2014, 65, 173-185. [CrossRef]

35. Oram, N.J.; van de Voorde, T.F.J.; Ouwehand, G.-J.; Bezemer, T.M.; Mommer, L.; Jeffery, S.; Van Groenigen, J.W. Soil amendment with biochar increases the competitive ability of legumes via increased potassium availability. Agric. Ecosyst. Environ. 2014, 191, 92-98. [CrossRef] 
36. Deng, B.; Tammeorg, P.; Luukkanen, O.; Helenius, J.; Starr, M. Effects of Acacia seyal and biochar on soil properties and sorghum yield in agroforestry systems in South Sudan. Agrofor. Syst. 2017, 91, 137. [CrossRef]

37. Lehmann, J.; Kuzyakov, Y.; Pan, G.; Ok, Y.S. Biochars and the plant-soil interface. Plant Soil 2015, 395, 1-5. [CrossRef]

38. Ulrich, A.; Klimke, G.; Wirth, S. Diversity and Activity of Cellulose-Decomposing Bacteria, Isolated from a Sandy and a Loamy Soil after Long-Term Manure Application. Microb. Ecol. 2008, 55, 512. [CrossRef]

39. Wilson, D.O.; Reisenauer, H.M. Determination of Leghemoglobin in Legume Nodules. Anal. Biochem. 1963, 6, 27-30. [CrossRef]

40. Nelson, D.W.; Sommers, L.E. Total Carbon, Organic Carbon and Organic Matter. In Methods of Soil Analysis, Part 2. Chemical and Microbiological Properties, 2nd ed.; ASA-SSSA: Madison, WI, USA, 1982; pp. 539-579.

41. ISO 13536:1995. Soil Quality-Determination of the Potential Cation Exchange Capacity and Exchangeable Cations Using Barium Chloride Solution Buffered at $p H=8.1$; International Organization for Standardization: Geneva, Switzerland, 1995.

42. Zuur, A.F.; Ieno, E.N.; Smith, G.M. Principal Component Analysis and Redundancy Analysis. Anal. Ecol. Data Stat. Biol. Heal. 2007, 193-224. [CrossRef]

43. Bonser, S.P.; Aarssen, L.W. Allometry and Plasticity of Meristem Allocation throughout Development in Arabidopsis Thaliana. J. Ecol. 2001, 89, 72-79. [CrossRef]

44. Bonser, S.P.; Aarssen, L.W. A Llometry and Development in Herbaceous Plants: Functional Responses of Meristem Allocation To Light and Nutrient Availability 1. Am. J. Bot. 2003, 90, 404-412. [CrossRef]

45. Caton, B.P.; Foin, T.C.; Hill, J.E. Phenotypic Plasticity of Ammannia Spp. in Competition with Rice. Weed Res. 1997, 37, 33-38. [CrossRef]

46. Gascó, G.; Cely, P.; Paz-Ferreiro, J.; Plaza, C.; Méndez, A. Relation between biochar properties and effects on seed germination and plant development. Biol. Agric. Hortic. 2016, 32, 237-247. [CrossRef]

47. Zhang, H.; Zhou, D.; Huang, Y.; Japhet, W.; Sun, D. Plasticity and Allometry of Meristem Allocation in Response to Density in Three Annual Plants with Different Architectures. Botany 2008, 86, 1291-1298. [CrossRef]

48. Roitsch, T. Source-Sink Regulation. Curr. Opin. Plant Biol. 1999, 2, 198-206. [CrossRef]

49. Liang, C.; Zhu, X.; Fu, S.; Mendez, A.; Gasco, G.; Paz-Ferreiro, J. Biochar alters the resistance and resilience to drought in a tropical soil. Environ. Res. Lett. 2014, 9, 064013. [CrossRef]

50. Bellaloui, N.; Mengistu, A.; Kassem, M.A. Effects of Genetics and Environment on Fatty Acid Stability in Soybean Seed. Food Nutr. Sci. 2013, 4, 165-175. [CrossRef]

51. Rajabbeigi, E.; Eichholz, I.; Beesk, N.; Ulrichs, C.; Kroh, L.W.; Rohn, S.; Huyskens-Keil, S. Interaction of Drought Stress and UV-B Radiation-Impact on Biomass Production and Flavonoid Metabolism in Lettuce (Lactuca sativa L.). J. Appl. Bot. Food Qual. 2013, 86, 190-197. [CrossRef]

52. Güereña, D.T.; Lehmann, J.; Thies, J.E.; Enders, A.; Karanja, N.; Neufeldt, H. Partitioning the Contributions of Biochar Properties to Enhanced Biological Nitrogen Fixation in Common Bean (Phaseolus vulgaris). Biol. Fertil. Soils 2015, 51, 479-491. [CrossRef]

53. Butnan, S.; Deenik, J.L.; Toomsan, B.; Antal, M.J.; Vityakon, P. Biochar Characteristics and Application Rates Affecting Corn Growth and Properties of Soils Contrasting in Texture and Mineralogy. Geoderma 2015, 237, 105-116. [CrossRef]

54. Novak, J.; Busscher, W.; Laird, D.; Ahmedna, M.; Watts, D.W.; Niandou, M. Impact of Biochar Amendment on Fertility of a Southeastern Coastal Plain Soil. Soil Sci. 2009, 174, 105-112. [CrossRef]

55. Shinogi, Y.; Yoshida, H.; Koizumi, T.; Yamaoka, M.; Saito, T. Basic Characteristics of Low-Temperature Carbon Products from Waste Sludge. Adv. Environ. Res. 2003, 7, 661-665. [CrossRef]

56. Major, J.; Lehmann, J.; Rondon, M.; Goodale, C. Fate of Soil-Applied Black Carbon: Downward Migration, Leaching and Soil Respiration. Glob. Chang. Biol. 2010, 16, 1366-1379. [CrossRef]

57. Appleby, C.A. Leghaemoglobin and Rhizobium respiration. Annu. Rev. Plant Physiol. 1984, 35, $443-478$. [CrossRef]

58. Ohyama, T.; Yashima, H.; Tanabata, S.; Ishikawa, S.; Sato, T.; Nishiwaki, T.; Ohtake, N.; Sueyoshi, K.; Ishii, S.; Fujimaki, S. Effect of Nitrate on Nodulation and Nitrogen Fixation of Soybean. Soybean Physiol. Biochem. 2011, 333-364. [CrossRef]

59. Singh, S.; Varma, A. Rhizobium Biology and Biotechnology 15Structure, Function, and Estimation of Leghemoglobin. Soil Biol. 2017, 50, 309-330. [CrossRef] 
60. Clúa, J.; Roda, C.; Zanetti, M.E.; Blanco, F.A. Compatibility between Legumes and Rhizobia for the Establishment of a Successful Nitrogen-Fixing Symbiosis. Genes 2018, 9, 125. [CrossRef] [PubMed]

61. Sprent, J.I. The effects of water stress on nitrogen-fixing root nodules. New Phytol. 1971, 70, 9-17. [CrossRef]

62. Graham, P.H. Stress Tolerance in Rhizobium and Bradyrhizobium, and Nodulation under Adverse Soil Conditions. Can. J. Microbiol. 1992, 38, 475-484. [CrossRef]

63. Serraj, R.; Vadez, V.; Denison, R.F.; Sinclair, T.R. Involvement of Ureides in Nitrogen Fixation Inhibition in Soybean1. Plant Physiol. 1999, 119, 289-296. [CrossRef]

64. Egamberdieva, D.; Hua, M.; Wirth, S.; Bellingrath-kimura, D. Potential Effects of Biochar-Based Microbial Inoculants in Agriculture. Environ. Sustain. 2018, 1, 19-24. [CrossRef]

65. Peng, W.T.; Zhang, L.D.; Zhou, Z.; Fu, C.; Chen, Z.C.; Liao, H. Magnesium Promotes Root Nodulation through Facilitation of Carbohydrate Allocation in Soybean. Physiol. Plant. 2018, 163, 372-385. [CrossRef]

66. Sangakkara, U.R.; Hartwig, U.A.; Nösberger, J. Soil Moisture and Potassium Affect the Performance of Symbiotic Nitrogen Fixation in Faba Bean and Common Bean. Plant Soil 1996, 184, 123-130. [CrossRef]

67. Sardans, J.; Peñuelas, J.; Ogaya, R. Experimental Drought Reduced Acid and Alkaline Phosphatase Activity and Increased Organic Extractable P in Soil in a Quercus Ilex Mediterranean Forest. Eur. J. Soil Biol. 2008, 44, 509-520. [CrossRef]

68. Yu, O.Y.; Raichle, B.; Sink, S. Impact of Biochar on the Water Holding Capacity of Loamy Sand Soil. Int. J. Energy Environ. Eng. 2013, 4, 1-9. [CrossRef]

69. Colvan, S.R.; Syers, J.K.; O'Donnell, A.G.O. Effect of Long-Term Fertiliser Use on Acid and Alkaline Phosphomonoesterase and Phosphodiesterase Activities in Managed Grassland. Biol. Fertil. Soils 2001, 34, 258-263. [CrossRef]

70. Nannipieri, P.; Giagnoni, L.; Landi, L.; Renella, G. Phosphorus in Action. Soil Biol. 2011, 26, $215-243$. [CrossRef]

71. Warnock, D.D.; Lehmann, J.; Kuyper, T.W.; Rillig, M.C. Mycorrhizal Responses to Biochar in Soil-Concepts and Mechanisms. Plant Soil 2007, 300, 9-20. [CrossRef]

72. Blackwell, M.S.A.; Brookes, P.C.; de la Fuente-Martinez, N.; Gordon, H.; Murray, P.J.; Snars, K.E.; Williams, J.K.; Bol, R.; Haygarth, P.M. Phosphorus Solubilization and Potential Transfer to Surface Waters from the Soil Microbial Biomass Following Drying-Rewetting and Freezing-Thawing, 1st ed.; Elsevier Inc.: Amsterdam, The Netherlands, 2010; Volume 106. [CrossRef]

73. Antoun, H. Beneficial Microorganisms for the Sustainable Use of Phosphates in Agriculture. Procedia Eng. 2012, 46, 62-67. [CrossRef]

74. Vassilev, N.; Martos, E.; Mendes, G.; Martos, V.; Vassileva, M. Biochar of Animal Origin: A Sustainable Solution to the Global Problem of High-Grade Rock Phosphate Scarcity? J. Sci. Food Agric. 2013, 93, 1799-1804. [CrossRef]

75. Gul, S.; Whalen, J.K. Biochemical Cycling of Nitrogen and Phosphorus in Biochar-Amended Soils. Soil Biol. Biochem. 2016, 103, 1-15. [CrossRef]

76. Van Zwieten, L.; Rose, T.; Herridge, D.; Kimber, S.; Rust, J.; Cowie, A.; Morris, S. Enhanced Biological N2 Fixation and Yield of Faba Bean (Vicia faba L.) in an Acid Soil Following Biochar Addition: Dissection of Causal Mechanisms. Plant Soil 2015, 395, 7-20. [CrossRef]

77. Marschner, H.; Marschner, H. 7-Nitrogen Fixation. Miner. Nutr. High. Plants 1995, 2, 201-228. [CrossRef]

78. Quilliam, R.S.; DeLuca, T.H.; Jones, D.L. Biochar Application Reduces Nodulation but Increases Nitrogenase Activity in Clover. Plant Soil 2013, 366, 83-92. [CrossRef]

79. Indrasumunar, A.; Menzies, N.W.; Dart, P.J. Calcium Affects the Competitiveness of Acid-Sensitive and Acid-Tolerant Strains of Bradyrhizobium Japonicum in Nodulating and Fixing Nitrogen with Two Soybean Cultivars in Acid Soil. Soil Biol. Biochem. 2012, 46, 115-122. [CrossRef]

80. Haynes, R.J. Effects of Liming on Phosphate Availability in Acid Soils-A Critical Review. Plant Soil 1982, 68, 289-308. [CrossRef]

(C) 2019 by the authors. Licensee MDPI, Basel, Switzerland. This article is an open access article distributed under the terms and conditions of the Creative Commons Attribution (CC BY) license (http://creativecommons.org/licenses/by/4.0/). 